\title{
APLIKASI NANOENKAPSULASI MINYAK KOPI SPECIALTY DENGAN BERBAGAI ENKAPSULAN MENGGUNAKAN METODE FREEZE DRYING
}

\author{
NANOENKAPSULATION OF SPECIALTY COFFEE OIL WITH A VARIETY OF \\ ENCIPULATIONS USING THE FREEZE DRYING METHOD
}

\author{
Masrukan dan Iva Mindhayani \\ Prodi Teknologi Pangan, Fakultas Sains dan Teknologi Universitas Widya Mataram \\ Email : mrukan@gmail.com
}

Diserahkan [7 Desember 2018]; Diterima [25 Juni 2020]; Dipublikasi [3 Juli 2020]

\begin{abstract}
Coffee oil extracted from specialty coffee beans has a variety of flavors that are susceptible to damage during storage and processing, so efforts are needed to prevent this damage by nanoencapsulation. Nanoencapsulation is a good way to convert specialty coffee oils from liquid to powder form so it is more stable and has a long shelf life. The encapsulants used are chitosan, maltodesctrin, and a mixture of both. This study aims to determine the physical and chemical characteristics of coffee oil nanocapsules by using the freeze drying method. Physical characteristics of specialty coffee oil nanocapsules: $1.88 \%$ moisture content, $92.3 \%$ solubility, $17.8 \%$ hygroscopicity and oval and irregular morphology. Application of nanoencapsulation in specialty coffee oil is expected to be able to meet the needs of a flavoring agent as a safe food additive with long shelf life.
\end{abstract}

Keywords: specialty coffee oil, flavoring agent, nanoencapsulation, freeze drying

\begin{abstract}
ABSTRAK
Minyak kopi yang diekstrak dari biji kopi specialty mempunyai beragam jenis flavor yang rentan terhadap kerusakan selama penyimpanan dan pengolahan sehingga perlu upaya untuk mencegah kerusakan tersebut dengan nanoenkapsulasi. Nanoenkapsulasi merupakan salah satu cara yang baik untuk mengubah minyak kopi specialty dari bentuk cair ke bantuk powder sehingga lebih stabil dan mempunyai daya simpan yang lama. Enkapsulan yang digunakan adalah kitosan, maltodesktrin, dan campuran keduanya. Penelitian ini bertujuan untuk mengetahui karakteristik fisik dan kimia nanokapsul minyak kopi dengan menggunakan metode freeze drying. Karakteristik fisik dari nanokapsul minyak kopi specialty:, kadar air 1,88\%, kelarutan 92,3\%, higroskopisitas $17,8 \%$ dan morfologi nanokapsul berbentuk oval dan tidak beraturan. Aplikasi nanoenkapsulasi pada minyak kopi specialty diharapkan mampu memenuhi kebutuhan flavouring agent sebagai bahan tambahan pangan yang aman dengan daya simpan yang lama.
\end{abstract}

Kata kunci: minyak kopi specialty, flavouring agent, nanoenkapsulasi, freeze drying

\section{PENDAHULUAN}

Kopi merupakan salah satu komoditas utama perdagangan dari hasil pertanian, nomor ke-2 di dunia setelah minyak bumi (Naidu dkk., 2008). Kopi Arabika Okbab Speciality tumbuh pada ketinggian $2750 \mathrm{dpl}$, curah hujan tahunan mencapai $5.000 \mathrm{~mm}$, suhu berkisar antara $12-24^{\circ} \mathrm{C}$ dengan kondisi tanah vulkanik Kopi specialty mempunyai beragam jenis flavor spesifik dan antioksidan, apabila dibandingkan dengan kopi biasa pada umumnya (Piccino Sebastien dkk, 2014). Biji kopi mengandung minyak antara $7-17 \%$. Kopi arabika mengandung minyak lebih tinggi, rata-rata sekitar $15 \%$, sedangkan kopi robusta rata-rata hanya mengandung minyak 10\%. Minyak kopi dapat diperoleh dari biji kopi (green coffee oil) atau dari kopi biji yang telah disangrai (roasted coffee oil). Penyangraian pada biji menghasilkan senyawa yang bertanggung jawab terhadap flavor kopi. Minyak kopi yang diperoleh dari biji kopi sangrai dapat digunakan sebagai flavoring agent pada bahan pangan. Penggunaan minyak kopi tersebut antara lain untuk memperbaiki minuman yang berbahan dasar kopi (coffee beverages), sebagai flavoring pada makanan antara lain permen (candies), kue, dan pudding (Frascareli dkk., 2011). 
Minyak kopi telah banyak dimanfaatkan sebagai zat antikarsinogen (Hatzold, 2012), antioksidan dan antiperadangan (Lee, K. J dkk., 2017). Meskipun banyak digunakan dalam berbagai bidang, minyak kopi yang diekstrak dari biji kopi specialty mengandung asam lemak tidak jenuh sehingga rentan terhadap suhu tinggi, oksidasi, sinar UV dan kelembapan udara. Salah satu kerusakan oksidatif pada minyak kopi adalah timbul bau dan rasa tidak enak, stabilitas umur simpan menurun serta berpengaruh pada sifat sensoris (Oliviera dkk, 2005). Salah satu upaya untuk mencegah kerusakan tersebut adalah dengan cara enkapsulasi.

Nanoenkapsulasi adalah teknologi untuk melindungi zat dalam ukuran kecil yang mengacu pada kemasan bioaktif pada kisaran nano yakni $10^{-9} \mathrm{~nm}$ (Ezhilarsie dkk., 2012). Sehingga nanoenkapsulasi mempunyai potensi untuk menjaga dari kehilangan flavor pada minyak kopi specialty dengan cara menghambat evaporasi pada minyak kopi. Partikel dengan ukuran nano memungkinkan terjadinya distribusi yang lebih baik pada produk serta dapat memperluas permukaan kontak partikel dengan bahan. Selain itu, nanoenkapsulasi memungkinkan bahan aktif yang ada pada minyak kopi untuk lepas secara berkala melalui lapisan enkapsulan, sehingga hal ini juga dapat meningkatkan efisiensi penggunaan bahan aktif (Won dkk., 2008).

Salah satu metode nanoenkapsulasi pada bahan inti yang mudah megalami kerusakan akibat panas adalah freeze drying. Beberapa faktor yang dapat mempengaruhi retensi senyawa bioaktif dalam nanokapsul minyak kopi specialty hasil freeze drying diantaranya adalah jenis enkapsulan, konsentrasi enkapsulan dan rasio antara kopi dengan enkapsulan. Pemilihan enkapsulan untuk mendapatkan ukuran nano sangat menentukan keberhasilan nanoenkapsulasi. Kitosan dan maltodekstrin telah digunakan untuk proses enkapsulasi berbagai jenis senyawa bioaktif dan flavor. Kitosan memberikan perlindungan yang baik terhadap bahan inti dan dapat mengikat senyawa bioaktif yang ada pada bahan inti, sementara maltodekstrin memiliki kelarutan yang tinggi, tidak mempunyai rasa dan aroma, serta baik untuk melindungi flavor dari oksidasi (Saloko dkk., 2012).

Penelitian tentang nanoenkapsulasi minyak kopi specialty dengan berbagai kombinasi enkapsulan belum banyak diteliti, sehingga aplikasi nanoenkapsulasi diharapkan mampu menghasilkan nanokapsul minyak kopi specialty yang lebih stabil dalam melindungi komponen volatil dan bioaktif selama penyimpanan.

\section{METODE PENELITIAN}

\section{Bahan}

Minyak kopi diekstrak dari kopi sangrai specialty Okbab, Papua $\left(160^{\circ} \mathrm{C}, 1,5\right.$ jam $)$ menggunakan pelarut heksana dengan perbandingan $(1: 4 \mathrm{~b} / \mathrm{v})$ menggunakan rotary evaporator pada suhu $50-60^{\circ} \mathrm{C}$ selama 6 jam. Ekstrak minyak kopi disimpan dalam botol gelap di dalam cold storage dengan suhu $4^{\circ} \mathrm{C}$ sampai digunakan dalam penelitian. Enkapsulan yang digunakan kitosan dan maltodekstrin Sigma Aldrich (Steinheim, Germany).

Tabel 1 Komposisi campuran minyak kopi dengan berbagai enkapsulan

\begin{tabular}{clc}
\hline Perlakuan & \multicolumn{1}{c}{ Enkapsulan } & Rasio minyak kopi dengan ekapsulan \\
\hline A1 & Kitosan & $1: 10(\mathrm{v} / \mathrm{v})$ \\
A2 & Maltodekstrin & $1: 10(\mathrm{v} / \mathrm{v})$ \\
A3 & Kitosan + maltodekstrin $(50: 50)$ & $1: 10(\mathrm{v} / \mathrm{v})$ \\
A4 & Kitosan + maltodekstrin $(25: 75)$ & $1: 10(\mathrm{v} / \mathrm{v})$ \\
A5 & Kitosan + maltodekstrin $(75: 25)$ & $1: 10(\mathrm{v} / \mathrm{v})$ \\
\hline
\end{tabular}

\section{Metode Penelitian}

\section{Nanoenkapsulasi Minyak Kopi}

Tahap ini bertujuan untuk membuat nanokapsul minyak kopi menggunakan penyalut kitosan, maltodekstrin, dan kombinasi keduanya, kemudian dikarakterisasi sifat fisik dan kimianya. Nanokapsul dibuat dari campuran minyak kopi dengan berbagai enkapsulan: kitosan, 
maltodekstrin, dan kombinasi keduanya (Tabel 1) yaitu 1:10 v/v. Kemudian campuran dihomogenisasi dengan menggunakan magnetic stirrer 5 menit sampai homogen, sehingga terbentuk suatu emulsi. Selanjutnya dilakukan pengecilan partikel emulsi menjadi nanopartikel dengan menggunakan dispersing machine ( $\mathrm{T} 25$ digital ultra-turrax, IKA, China) $20.000 \mathrm{rpm}$ selama 20 menit. Setelah terbentuk sistem nanoemulsi, kemudian dikeringkan dengan menggunakan freeze dryer selama 48 jam.

\section{Metode Analisis}

Analisa komposisi kadar air menggunakan analisa gravimetri (AOAC, 1990), kelarutan mikrokapsul (Chen and Jane, 1994 dengan modifikasi). Morfologi nanokapsul dianalisa dengan Scanning Electron Microscope (SEM type JSM-6510 type LA, USA).

\section{HASIL DAN PEMBAHASAN}

\section{Kadar Air Nanokapsul}

Berdasarkan Gambar 1 diperoleh hasil kadar air nanokapsul yang dihasilkan pada penelitian ini berkisar antara 1,05-1,94\% dan tidak menunjukkan perbedaan yang nyata pada perlakuan konsentrasi enkapsulan $(p<0,05)$.
Nilai kadar air yang diperoleh dalam penelitian ini merupakan nilai yang kecil untuk kadar air nanokapsul sehingga bisa diartikan bahwa hampir sebagian besar air dalam kapsul menguap dalam proses atomisasi pada waktu proses freeze drying. Kecilnya kadar air juga dipengaruhi oleh karakteristik enkapsulan yang digunakan. Meskipun hasil kadar air nanokapsul minyak kopi tidak berbeda nyata secara statistik, Tonon et al. (2011) bahwa acai juice powder yang disalut dengan gum arabic memiliki kadar air lebih tinggi dibanding dengan acai juice powder yang disalut dengan maltodekstrin.

\section{Kelarutan Nanokapsul}

Kelarutan nanokapsul berhubungan dengan penggunaanya dalam bahan pangan (Gambar 2). Semakin mudah larut, maka akan semakin mudah dalam penanganan proses. Kelarutan merupakan kemampuan suatu zat terlarut untuk dapat larut dalam suatu pelarut tertentu pada keadaan tertentu membentuk larutan homogen (Chen and Jane, 1994). Nanokapsul minyak kopi dengan konsentrasi penyalut $10 \%(\mathrm{w} / \mathrm{v})$ dan rasio enkapsulan kitosan dan maltodekstrin (75:25) yaitu 92,31\%. Nilai kelarutan tersebut tergolong tinggi disebabkan oleh kandungan maltodekstrin sebagai penyalut, dimana maltodekstrin memiliki kelarutan yang tinggi di dalam air maupun minyak.

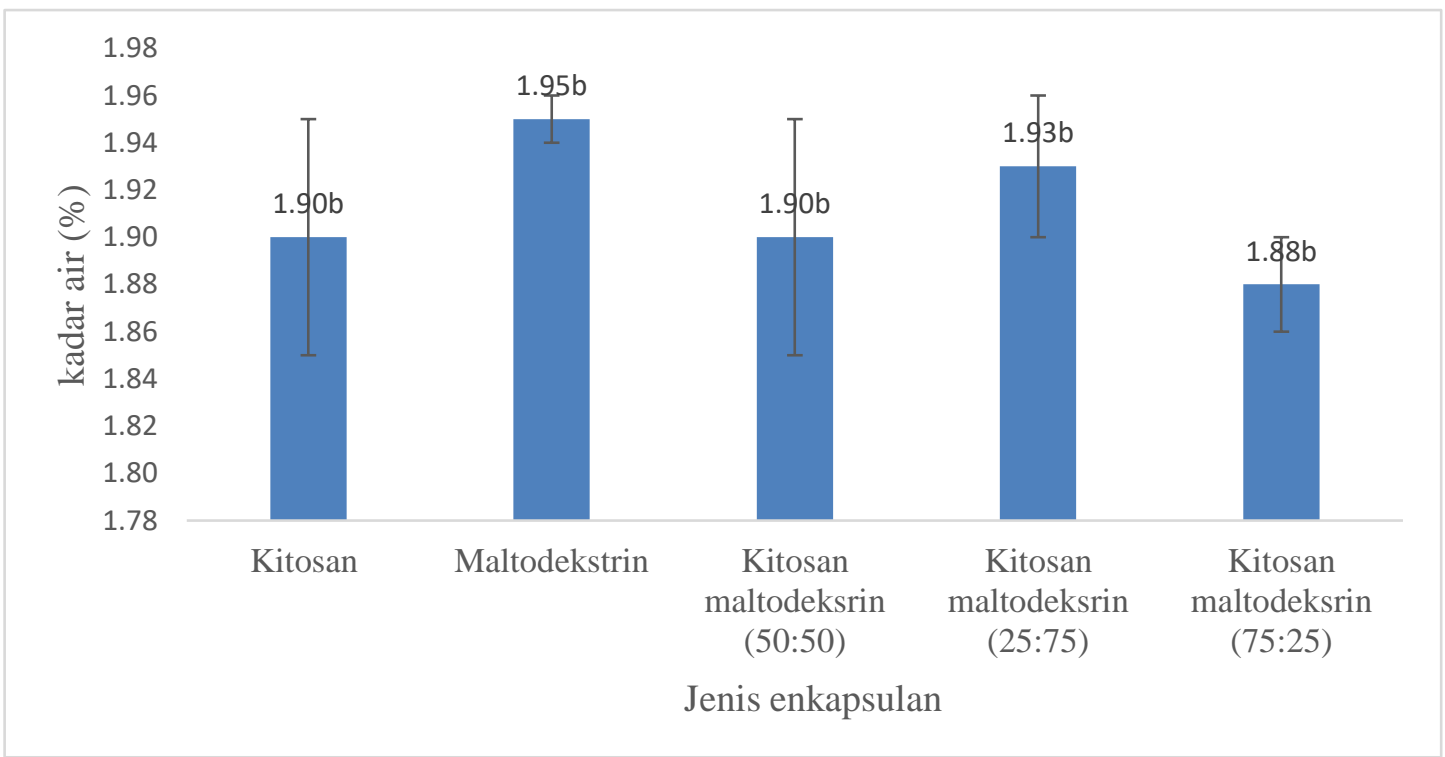

Gambar 1 Kadar air (Ka) nanokapsul dengan enkapsulan kitosan dan maltodekstrin. Huruf yang berbeda di belakang angka pada histogram menunjukkan perbedaan nyata $(p<0,05)$ 


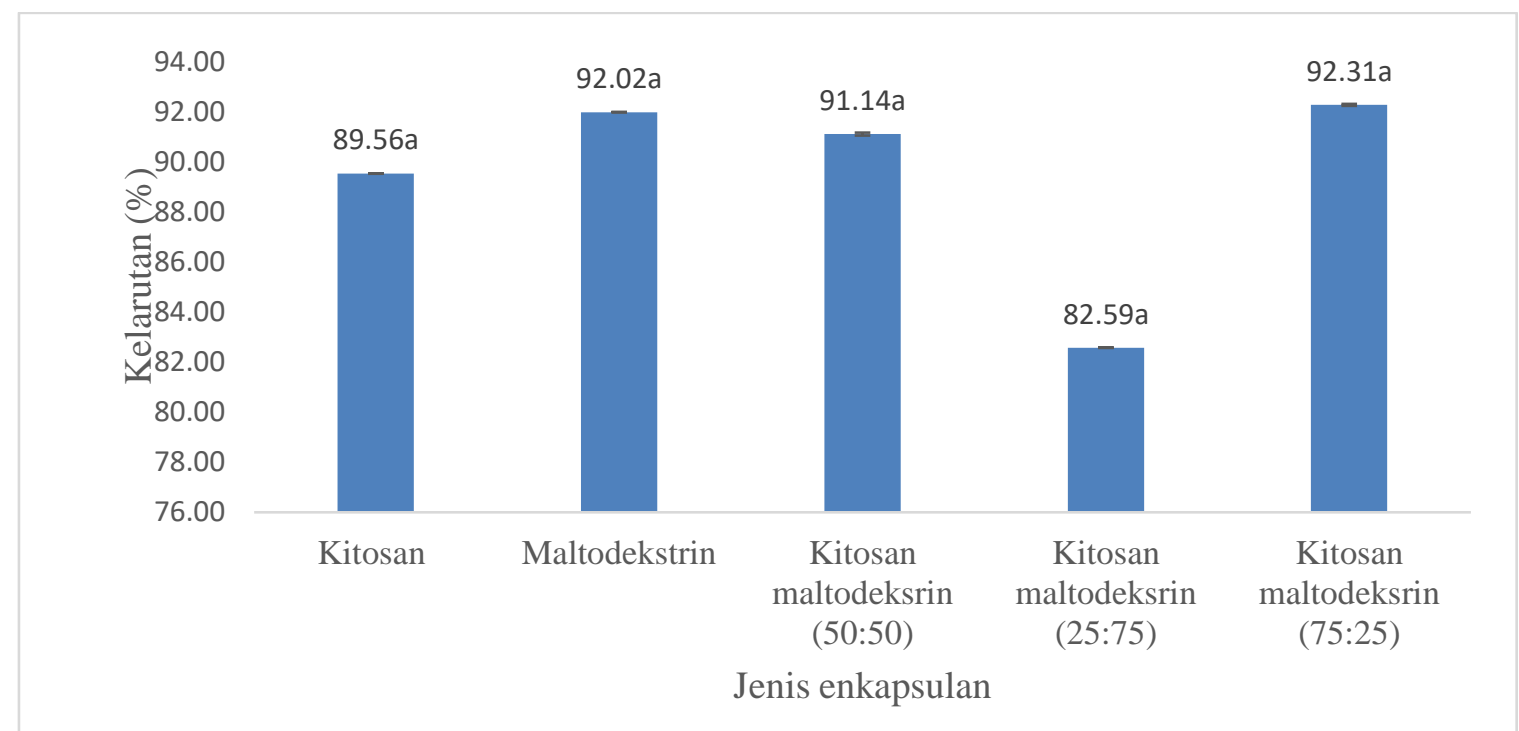

Gambar 2 Kelarutan nanokapsul dengan enkapsulan kitosan dan maltodekstrin. Huruf yang berbeda di belakang angka pada histogram menunjukkan perbedaan nyata $(p<0,05)$

Secara statistik tiap perlakuan tidak menunjukkan perbedaan yang signifikan. Artinya setiap perlakuan menunjukkan nilai persen kelarutan yang sama. Mozafari et al. (2006) menyatakan bahwa dengan teknik mikroenkapsulasi dapat menghasilkan produk yang memiliki luas permukaan lebih besar; meningkatkan kelarutan, bioavailabilitas dan controll release. Sesuai dengan hal tersebut, dalam penelitian ini telah dihasilkan produk nanokapsul yang memiliki kelarutan tinggi sehingga diharapkan nantinya apabila diaplikasikan akan mempermudah dalam proses pengolahan.

\section{Higroskopisitas Nanokapsul}

Higroskopis nanokapsul sangat dipengaruhi oleh sifat bahan inti dan penyalut yang digunakan. Nanokapsul yang dihasilkan pada penelitian ini memiliki higroskopisitas yang cukup tinggi berkisar relatif tinggi didapatkan pada nanokapsul minyak kopi dengan konsentrasi enkapsulan kitosan dan maltodekstrin (50:50) yaitu 19,17\%, meskipun pada campuran kitosan dan maltodekstrin (50:50) menunjukan nilai higroskopisitas yang tidak berbeda nyata pada nilai higroskopisitas yang relatif tinggi. Higroskopisitas nanokapsul minyak kopi kopi dapat dilihat pada Gambar 3.

Hal ini disebabkan karena konsentrasi bahan inti yang rendah dan sifat higroskopis bahan enkapsulan menyebabkan nanokapsul menyerap air dalam jumlah banyak. Enkapsulan maltodesktrin memiliki sifat yang sangat higroskopis setelah proses pengeringan, bahan langsung menyerap uap air, makin banyak uap air yang diserap oleh bahan maka makin tinggi kadar airnya. Sehingga dapat disimpulkan bahwa higroskopisitas nanokapsul yang terbaik sangat dipengaruhi oleh besarnya konsentrasi enkapsulan. 


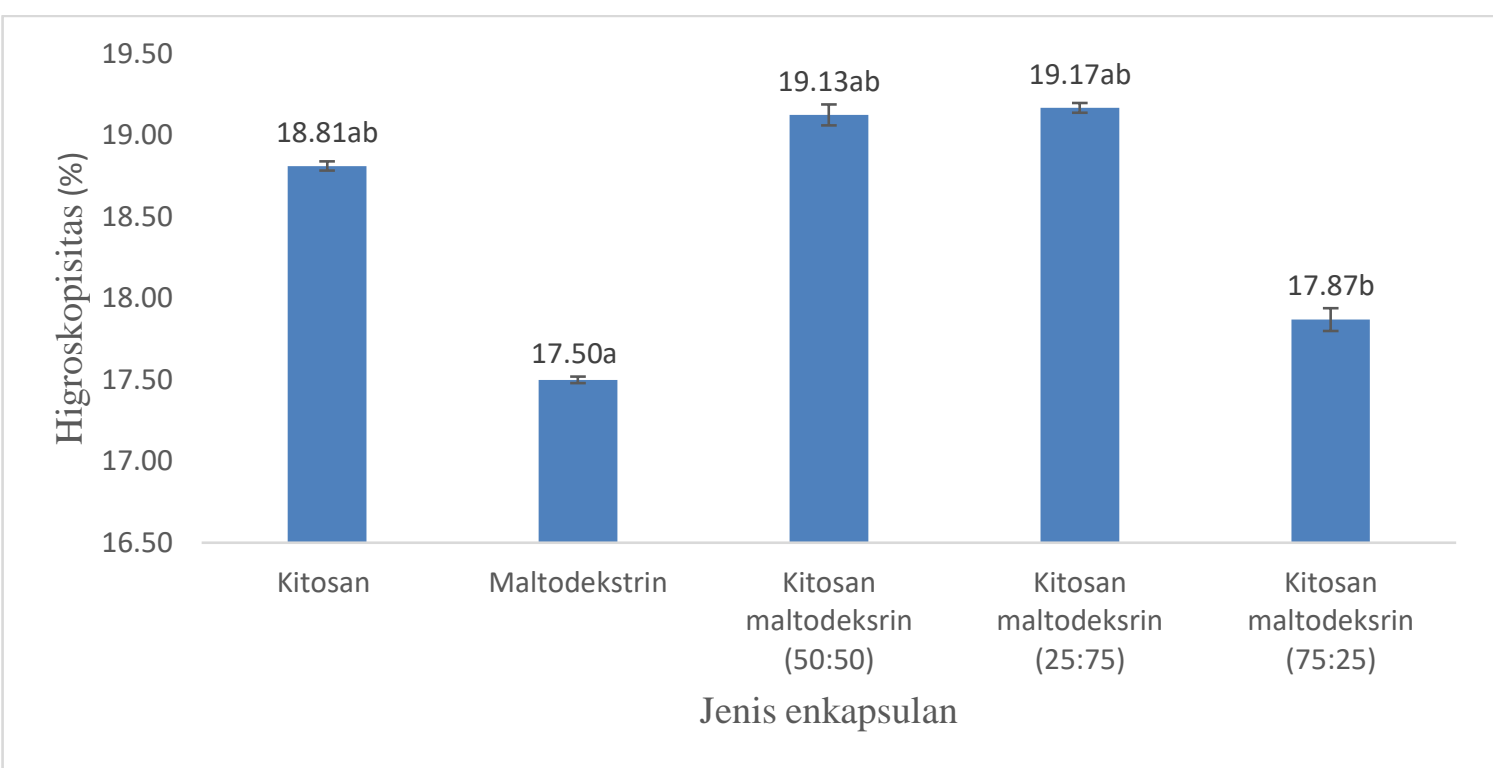

Gambar 3 Higroskopisitas nanokapsul minyak kopi Okbab dengan enkapsulan. Huruf yang berbeda di belakang angka pada histogram menunjukkan perbedaan nyata $(p<0,05)$

\section{Profil SEM nanokapsul}

Struktur nanokapsul mempengaruhi karakteristik nanokapsul. Nanokapsul diamati dengan menggunakan Scanning Electron Microscope (SEM) yang bertujuan untuk melihat bentuk dan tekstur dari partikelnya. Berikut ini adalah Gambar 4 yang menampilkan kenampakan partikel nanokapsul minyak kopi specialty dengan bahan penyalut kitosan dan maltodekstrin (75:25).

Pada Gambar 4 dapat dilihat profil morfologi nanokapsul berbentuk seperti serpihan tidak beraturan dan berongga, pada bagian dalam kapsul terlihat minyak kopi sedangkan lapisan luar merupakan enkapsuslan (maltodekstin dan kitosan). Kapsul mengalami aglomerasi karena pengeringan dengan menggunakan metode freeze drying tidak mampu memisahkan antar nanokapsul yang terbentuk. Selain itu, proses penggerusan nanokapsul menyebabkan kapsul berbentuk serpihan tipis yang tidak merata, bentuk inilah yang diharapkan pada nanoenkapsulasi untuk melindungi senyawa aktif dari kerusakan akibat pengaruh panas dan oksigen (Goubet et al. 1998). Bentuk kapsul ini juga serupa dengan yang diperoleh oleh Charikleia dan Constantina, (2014) pada enkapsulasi fennel oleoresin dengan enkapsulan gum arabic yang dikombinasi dengan pati termodifikasi, maltodekstrin dan kitosan, menggunakan pengeringan freeze drying. Meskipun masih mengalami aglomerasi namun permukaan nanokapsul tampak mulus dan tidak mengalami bocor atau cracking sehingga pelepasan bahan aktif flavor yang terkapsulkan tidak terjadi. 


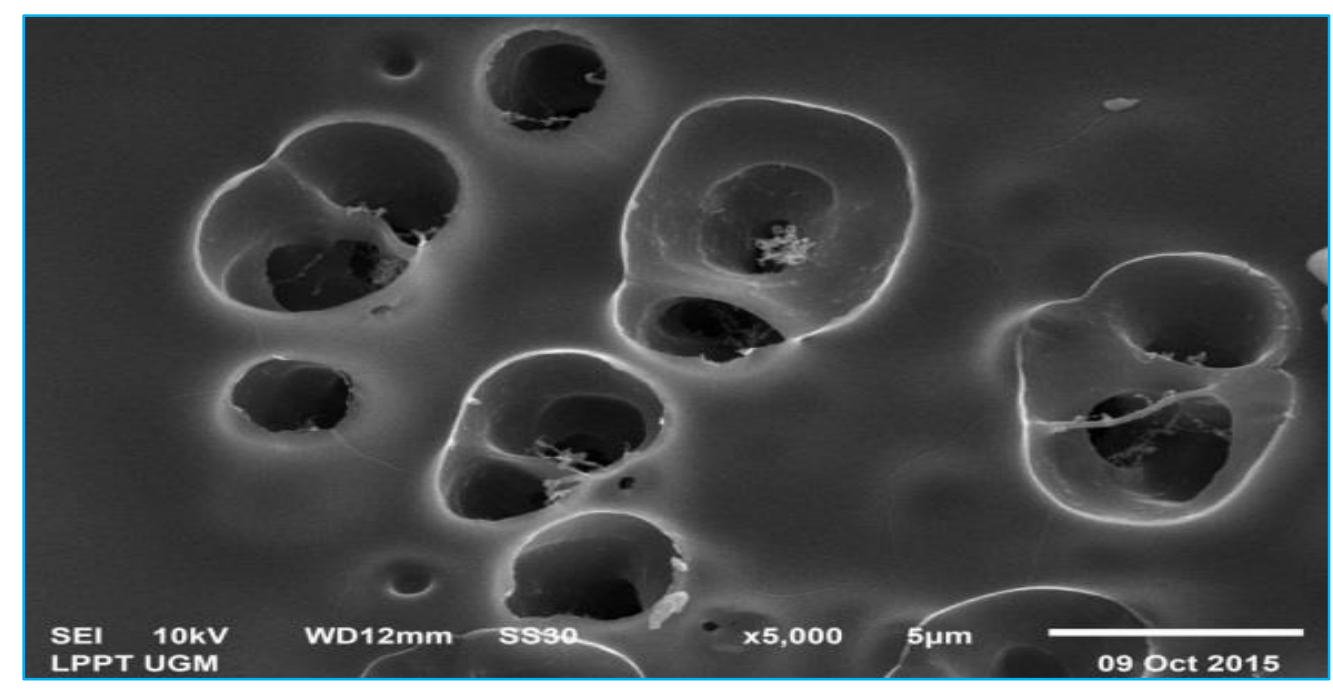

Gambar 4 Profil morfologi nanokapsul minyak kopi dengan perbesaran 5000 X

\section{KESIMPULAN}

Kondisi optimum pada nanoenkapsulasi minyak kopi specialty okbab dengan menggunakan metode freeze drying yaitu kombinasi enkapsulan kitosan dan maltodekstrin $(75: 25 \%)$. Karakteristik fisik dan kimia nanokapsul minyak kopi specialty okbab :, kadar air 1,88\%, kelarutan 92,3\%, higroskopisitas $17,8 \%$ dan morfologi nanokapsul berbentuk oval dan tidak beraturan.

\section{DAFTAR PUSTAKA}

Association of Official Analytical Chemists (AOAC). 1990. Official Analytical Chemist Official Methods on Analysis. 18th Ed, Gaithersburg, Maryland

Charikleia Chranioti \& Constantina Tzia. 2014. Binary Mixtures of Modified Starch, Maltodextrin and Chitosan as Efficient Encapsulating Agents of Fennel Oleoresin. Food Bioprocess Technology 6:3238-3246.

Ezhilarsi, P.N., P. Kharthik., N. Channwal., and C. Anandharamakrishman. 2012. Nanoencapsulation Techniques for Food Bioactive Components: A Review. Review Paper Food Bioprocess Technology 6(6), 28-647.

Frascareli, E.C., Silva, V.M., Tonona,, R.V., and Hubinger, M.D. 2011. Pshysicochemical Properties of Coffee Oil Microcapsiles Produces by Spray
Drying. Food and bioproducts processing 90: 413-424.

Goubet, I., Le Quere, J. L., \& Voiley, A. J. 1998. Retention of aroma compounds by carbohydrates: influence of their physicochemical characteristics and of their physical state. A review. Journal of Agricultural and Food Chemistry, 46, 1981-1990.

Hatzold, T. 2012. Coffee: Emerging health effects and disease prevention. In Y. F. Chu (Ed.), Introduction (pp. 1-20). New York: John Wiley \& Sons, Ltd.

Lee, K. J., \& Jeong, H. G. 2007. Protective effects of kahweol and cafestol against hydro-gen peroxide-induced oxidative stress and DNA damage. Toxicology Letters.173, 80-87.

Mozafari M R, Flanagan J, Matia-Merino L, Awati A, Omri A, Suntres Z E and Singh H (2006) Recent trends in the lipid-based nanoencapsulation of antioxidants and their role in foods. Journal of the Science of Food and Agriculture 86 2038-4205.

Naidu, M.M., Sulochnamma, G., Sampathu, S.R., Srinivas, P. , 2008. Studies on extraction and antioxidant potential of green coffee. Food Chem. 107 (1), 377-384.

Oliveira, A.L., Cruz, P.M., Eberlin, M.N., Cabral, F.A., 2005. Brazilian roasted coffee oil obtained by mechanical 
expelling:compositional analysis by GC-MS. Ciênc. Tecnol. Aliment. 25(4),677-682.

Piccino Sebastian,Renaud Boulanger, Frederic Descroix, Alain Shum Cheong Sing. 2014. Aromatic composition and potent odorants of the "specialty coffee" brew "Bourbon Pointu" correlated to its three trade classifications. Food Research International 61: 264-271

Saloko, S., P. Darmadji., B. Setiaji., and Y. Pranoto. 2014. Antioxidative and Antimicrobial Activities of Liquid Smoke Nanocapsules using Chitosan and Maltodextrin and its Application on Tuna Fish Preservation. Journal of Food Bioscience. 7: 71-79

Standar Nasional Indonesia. 2008. Biji Kopi. SNI 01-2907-2008

Tonon, V.R., Brabet, C. and Hubinger, M. 2011. Spray drying of acai juice: Effect of inlet temperature and type of carrier agent. Journal of Food Processing and Preservation 5: 691-700.

Won, J., M.H. Oh., J.M. Oh., M.S. Kang., J.H. Choy., and S. Oh. 2008. Stability Analysis of Zinc OxideNanoencapsulated Conjugated Linoleic Acid and GammaLinolenic Acid Journal of Food Science. 73:8:N39-43. 